tact with the public will be secured by means of an Advisory Council acting in a consultative capacity, and it will be consulted by the Postmaster-General on questions of general policy. The Report is obviously a document of first importance, and we hope to discuss the Committee's recommendations in due course.

\section{Progress and the Scientific Worker}

WITH the great changes inherent in modern civilisation, a new outlook has become essential. Science, the handmaiden of progress, cannot be divorced from industry, administration, social problems, etc.; and with this point of view in mind, the new series of Progress, which is being published as Progress and the Scientific Worker, aims at giving voice to the new citizenship. Necessarily, therefore, within its covers will be found the joint expressions of the scientific and humanistic outlook. This is made possible since it is the official journal of the Association of Scientific Workers and the British Institute of Social Service. Progress, the first bi-monthly number of which is for July-August 1932, has made a splendid beginning. Sir John Russell contributes an informative article on "The Coming Generation". He gives an interesting résumé of recent advances in the agricultural sciences. For example, in the harvesting of an acre of wheat, hand work of olden days involved 32 man hours, the early machine 19 man hours, and the modern machine 4 man hours. But the reduction of these man hours by mechanisation has its drawbacks. On one farm in Norfolk, for example, until recently, 40 men were employed, and now, since its 'mechanisation', only 4 are employed. One of the greatest problems of to-day, which will inevitably be handed on to the coming generation, is the employment of such displaced men.

Crosely allied to the problems discussed in this article is the paradox of plenty, which is the subject of an article by Mr. Percy Alden. There is a surplus throughout the world of wheat, cotton, tea, coffee, rubber, oil, and tin. Poverty-stricken countries are no doubt desirous of buying, but the purchasing power is absent. Now, there are, according to Mr. Alden, two essentials to recovery from this world-wide depression : international agreement over debts, reparations, and armaments, and an attempt to settle the currency question which is crippling industry in many countries. The inevitable connexion of industrial development with creative science forms the basis of Sir Richard Gregory's suggestive and illuminating article entitled "Science and the Nation". Sir Richard gives many convincing examples of the "triple alliance ' of creative science, purposeful invention, and skilled labour, and the resulting conditions, which have proved of national and international importance. "Science not only creates new means of existence and new sources of employment by the discovery of new principles and substances, but also places extended use of power at the disposal of every one. . . . Modern technical achievement and scientific thought foreshadow a new economic structure for society in which they should be used to exercise decisive influence upon the major politics of the State as well as upon their administration." Through such activities unbounded possibilities are presented to the new generation, including the problem of the displaced man. power discussed by Sir John Russell. Besides other articles of general interest, the new journal contains scientific, social, industrial, and educational news, reviews, and notes. The price is $6 d$. per copy, and the annual subscription $5 s$.

\section{Mohenjo-daro Dating}

A FURTHer stage towards precision in the dating of the prehistoric civilisation of the Indus valley is marked by Mr. Emest Mackay's letter to the Times of Aug. 27. Mr. Mackay records the discovery at Mohenjo-daro of a fragment of a steatite vase which bears exactly the same intricate and very unusual pattern as a double vase of the second period of Susa. It was found at a depth of $28 \mathrm{ft}$. below datum, very little above water-level in the soil when the river is at its lowest. The inference that it was an import from Elam is borne out by the material of the frag. ment, a greenish-grey steatite identical with that of the Susa II. double vase. A conservative estimate for the dating of Susa II. would place the Mohenjo-daro find at about 2800 B.c. On the other hand, Mr. Mackay points out that the seal, of undoubted Indian workmanship, found by Dr. H. Frankfort at Tell Asmar, is inscribed with animals which occur commonly on seals and sealings at Mohenjo-daro (although as yet only two cylinder seals have been found) and can be contemporaneous only with the upper levels of that site, occurring at some three to seven feet below datum. This, on the basis of Dr. Frankfort's dating of the Tell Asmar seal, would give a dating of 2500 B.c. for the upper levels at Mohenjo-daro-a reduction on the previous provisional dating. It would thus appear that between the lower levels, $28 \mathrm{ft}$. below datum, and the upper levels, contemporary with the period of the Tell Asmar find, some three hundred years elapse - a conclusion to which Mr. Mackay states that he already inclined on other grounds.

\section{Protection of Antiquities in France}

A QUESTION of much interest to archæologists in general, though naturally of more immediate moment to French archæologists, is raised by Dr. R. Vaufrey in the current issue of L'Anthropologie (t. 42, Nos. 3-4), in describing certain steps which have been taken by the Prehistoric Section of the Commission des Monuments historiques for the more efficient administration of the law relating to the protection of prehistoric antiquities. It would appear that French archæologists are feeling some alarm lest they should be on the eve of a condition of affairs prophesied by $\mathbf{M}$. Marcellin Boule more than forty years ago, when he foresaw that, unless effective measures were taken, France's priceless store of prehistoric antiquities in the Dordogne would be exhausted. In the opinion of prominent French archæologists, that time is indeed close at hand. Every effort is to be made to avert it. Present financial conditions preclude anything in the nature of the creation of a department for the purpose, but steps are being taken to secure a stricter enforcement of the existing law. The Prehistoric Section of 
the Commission, which is the body responsible, wishes to place no check on scientific excavation, whether by organisations or individuals properly accredited; but it aims at the ' amateur' who seeks to exploit a site for his personal and pecuniary gain. In this praiseworthy object, French archæologists will have the moral support of their colleagues, whatever their nationality, and also in what is clearly their secondary object, namely, to secure the control of the finds-thus averting such a catastrophe as occurred when the skeletal remains found in the caves of Le Moustier and Combe Capelle were lost to France.

Restoration of Roman Bridge, Littleborough, Lancs

ADVANTage has been taken of the unemployment problem at littleborough, Lancs, to invite the cooperation of voluntary workers among the unemployed on the 'dole' in the repair of the Roman road over Blackstone Edge. A part of the work contemplated has now been completed by the repair of the Roman bridge at the junction of Black Castle Clough and Rag Sapling Clough, which carries the road over Black Castle Clough. Some time ago, Mr. J. H. Price of Rochdale directed the attention of the Rochdale Literary and Seientific Society, and through it, of the Society for the Protection of Ancient Monu. ments, to the fact that the bridge was in danger of being swept away. Mr. Price's examination of the bridge had revealed the fact, which had been completely forgotten in the course of time, that originally it consisted of two culverts, one of which had collapsed and had become completely overgrown with grass. The original length of $25 \mathrm{ft}$. had thereby been reduced to $12 \mathrm{ft}$. This eulvert has now been restored and the bridge repaired, under Mr. Price's supervision, with the assistance of local firms who volunteered transport, material, etc. The work was carried out with the approval of H.M. Office of Works. Both Roman road and bridge are scheduled as ancient monuments. It is hoped to carry out repairs on part of the road in due course by the same method.

\section{Salamanders and the Pollution of Drinking Water}

A curious and unsuspected source of pollution of drinking-water has just been discovered in Cattaraugus County in western New York State (William G. Hassler in Natural History, New York, May-June, 1932, p. 303). Certain spring supplies of water continued to give unsatisfactory laboratory tests even after drastic steps had been taken to protect the springs from outside pollution. Further examination revealed that salamanders, large newt-like amphibians, belonging to four different species, occasionally occurred in the springs, and though a first examination showed that only a small percentage contained the colon bacillus, the investigation was continued. Nearly two hundred purple salamanders (Gyrinophilus porphyriticus) were marked with identification discs, and subsequent collecting proved that sometimes individuals wandered as much as sixty-five feet from the stream, apparently in search of food. One was observed eating fly larvæ which were living on mammalian refuse, and this settled the question of how colon bacilli entered the food canals of the salamanders. A second surprise was sprung upon the investigators when they studied more closely the numbers of salamanders in the springs themselves. Purple salamanders were not thought to be particularly common, but repeated nightly visits resulted in a catch of 144 in one spring, which contained about fifty more uncaught. Yet there were occasions when not one of these salamanders could be found, although all the catch was marked and returned to its spring. Laboratory experiments gave some idea of the extent to which contamination might take place. Over a period of 122 days, one salamander excreted a sufficient number of colon bacilli to contaminate 237 gallons of water heavily enough to be considered dangerous on every test. It is believed that the creatures act as reservoirs or incubators, and once infected with colon bacilli, continue to excrete them so long as there is food in the stomach or intestines to supply nourishment to the bacteria.

\section{Fishing with Captive Sucking Fish}

MoRe than four centuries ago, Columbus observed the strange custom of catching fish and turtles by meuns of captive sucking fish in the "Jardinellas de Ia Reina". The general impression has been that these islands were near Haiti and Jamaica, but C. Ralph de Sola points out that a more likely place is the archipelago in the Bight of Manzanillo on the south coast of Cuba (Copeia, p. 45, 1932). If this be so, Gudger is wrong in concluding that the original site of the discovery of Columbus " no longer witnesses the exploits of the fisherman fish ", for the Siboneyes of southern Cuba, a people of Carib extraction, still practice remora-fishing to a considerable extent. De Sola describes a fishing trip from Matanzas, Cuba. To the under-planks of the boat two sucking-fishes were firmly attached by their discs, and when a turtle was sighted basking on the surface, the fishes were detached and cast as far as possible towards the turtle. The sucking-fishes were themselves held captive by a long thin rope of majuga bark, attached in front of the tail, and so soon as they had fixed upon their quarry, the lines were drawn in and the captured hawk's-bill turtle taken aboard. Throughout the proceedings the lines had to be kept taut, and the author states that owing to the arrangement of the lamellæ of the sucker, it is impossible for the remora to relax its hold when tension is placed on its horizontal axis. It is curious that so peculiar a mode of fishing should be found in many distant parts of the world, but Gudger's records from various localities in Africa, Asia, Australia, South America, and the West Indies show that it is almost cosmopolitan in tropical seas.

\section{Eradication of Slugsand Snails}

IN a communication to NATURE on the eradication of slugs, which was the subject of a note in these columns on July 16 (p. 90), Mr. Walker Van Riper, 771 South High Street, Denver, Colorado, contributes another method of control based on his own experience. A generous distribution of a solution of ammonium sulphide ( 1 part in 30 parts of water) killed nearly all the slugs present in his garden in a single (Continued on p. 361.)

$$
\text { No. 3279, Vor. 130] }
$$

